\title{
PRKCA Gene
}

National Cancer Institute

\section{Source}

National Cancer Institute. PRKCA Gene. NCI Thesaurus. Code C24694.

This gene plays a role in numerous cellular processes such as adhesion, growth and volume control. It is also involved in memory function in the brain. 